\title{
Decolonising education in Africa: implementing the right to education by re-appropriating culture and indigeneity
}

\author{
FoluKe IfEJOLA AdEBISI*
}

Law School, University of Bristol

\begin{abstract}
Education in many African states is comparatively characterised by inadequate availability, accessibility, acceptability and adaptability of education. Nevertheless, evaluations focusing on lack of educational infrastructure and personnel usually ignore the contextual inadequacies of educational provision in the region and the inability of such education to equip its citizens to fit in with and benefit the societies they live in. This educational incompatibility has led to a significant level of unemployment/underemployment, underdevelopment and 'brain-drain', as well as some erosion of languages and cultures.

The colonial experience reduced education to a tool of communication between the coloniser and the colonised. Emphasis on the individual and de-emphasis on community and culture resulted in ideological dissonance. Despite post-independence attempts to reverse this, vestiges of postcoloniality in contemporary education remain and perpetuate a myth of inferiority of indigenous knowledge and methods. This deprives the world of a wider range of ways of knowing, pedagogy and epistemologies. The CESCR envisions education for the full development of the human personality of all people all over the world. Therefore, international initiatives promoting the right to education in Africa should take into account the particular positionality, historicity and needs of populations.

Using theories of deconstructive postcolonialism, this article will examine Africa's education narrative and suggest a critical Freirian approach for decolonising education in Africa. This article contends that undecolonised education results in epistemic violence/injustice and is thus pedagogically and ethically unsound - violating the right to education.
\end{abstract}

\section{Introduction}

$\mathrm{T}_{\mathrm{c}}^{\mathrm{h}}$ 1960 UN General Assembly Declaration on the Granting of Independence to Colonial Countries and Peoples demonstrated an international anticolonial consensus. The declaration asserted the 'necessity of bringing to a speedy and unconditional end colonialism in all its forms and manifestations' and proclaimed that 'the subjection of peoples to alien subjugation, domination and exploitation constitutes a denial of fundamental buman rights, is contrary to the Charter of the United Nations and is an impediment to the promotion of world peace and co-operation'. ${ }^{1}$

\footnotetext{
Teaching Associate. I wish to thank Professors Rachel Murray and Steven Greer as well as the anonymous reviewer - their input has enriched this article and myself.

1 Declaration on the Granting of Independence to Colonial Countries and Peoples, UN Doc A/RES 1514 (XV), 14 December 1960, para 1 (emphasis added).
} 
This was subsequent to a history of African agitation against colonial rule and its system. ${ }^{2}$ This included formal colonial education and economics; both were considered unfair and discriminatory. Agitators for independence believed that self-government would reverse this. ${ }^{3}$ At decolonisation, administration of all colonies was placed in the hands of Africans educated in colonial schools. ${ }^{4}$ However, colonial education had coloured indigenous African thought, classifying it as pre-logical and pre-critical, disregarding the fact that difference will not always suggest inferiority. ${ }^{5}$ Postindependence anticolonial initiatives informed by postcolonial writing on the subject have not sufficiently decolonised the socio-political, socio-cultural and socio-economic structures which were colonial inheritances. ${ }^{6}$ In 2016, the 'Rhodes Must Fall' educational decolonisation movement - started in South Africa with the removal of a statute of Cecil Rhodes - extended to Oxford in the UK. ${ }^{7}$ In non-African countries, this debate also suggests making curricula more inclusive.

In Africa, the promotion of the right to education, especially by international bodies, has been focused mainly on improving the availability and accessibility of education. African indigenous knowledge rarely features in this process. 'Indigenous knowledge' refers to precolonial African knowledge in and of Africa. It could be argued here that 'the concept of Africa', distinguished from the geographical entity, is both a colonial and postcolonial illusion, however, international engagement with sub-Saharan Africa especially, tends to disregard African state particularity and rather focuses on equal African paucity - supposed or otherwise. This article's treatment of 'Africa' is based in part on this prior engagement. As Nyamnjoh laments: 'Monological, non-reflexive and non-inclusive representations of parts of an arbitrarily mapped-out and confined Africa continue to be the dominant mode of comprehending the continent'. 8 Oelofsen posits that "Africa" denotes more than a geographical location'. She suggests that acknowledging the concept of Africa is to acknowledge the effect such conceptualisation has on intellectuality. ${ }^{9}$ It is this author's aim to simultaneously conceptualise and reconceptualise this form of representation.

Syrotinski's approach ${ }^{10}$ and the views of postcolonial African theorists prove very informative to the decolonisation process. Postcolonial deconstruction suggests the possibility and hope of a world of true equality of knowledge, philosophy and thought,

2 Michael Crowder, West Africa under Colonial Rule (Northwestern UP 1976) 467.

3 Ibid 469.

4 Ken Post, The New States of West Africa (Penguin African Library 1968) 42.

5 Barry Hallen, A Short History of African Philosophy (Indiana UP 2009) 38; Antony Anghie, Imperialism, Sovereignty and the Making of International Law (CUP 2007) 253; Barry Hallen, The Good, the Bad, and the Beautiful: Discourse about Values in Yoruba Culture (Indiana UP 2000) 2, 50; Francis B Nyamnjoh, "'Potted Plants in Greenhouses': A Critical Reflection on the Resilience of Colonial Education in Africa' (2012) 47(2) Journal of Asian and African Studies 136; Edward Shizha, 'Reclaiming our Memories: The Education Dilemma in Postcolonial African School Curricula' in Ali A Abdi and Ailie Cleghorn (eds), Issues in African Education (Palgrave Macmillan 2005) 67.

6 Peter Mayo, 'Nyerere's Postcolonial Approach to Education' in Ali A Abdi (ed), Decolonizing Philosophies of Education (Sense Publishers 2012) 43-47; Shizha (n 5) 75.

7 André Rhoden-Paul, 'Oxford Uni Must Decolonise its Campus and Curriculum, Say Students' The Guardian (24 March 2016) <www.theguardian.com/education/2015/jun/18/oxford-uni-must-decolonise-its-campusand-curriculum-say-students $>$.

8 Francis B Nyamnjoh, 'Blinded by Sight: Divining the Future of Anthropology in Africa' (2012) 47 Africa Spectrum 68.

9 Rianna Oelofsen, 'Decolonisation of the African Mind and Intellectual Landscape' (2015) 16(2) Phronimon 140.

10 See n 21 and text at n 41 below. 
a world where human rights are truly international. Spivak's writings on the subaltern explore the mechanisms of epistemological silencing, ${ }^{11}$ while Freire's ideas transform decolonisation possibility into potential. ${ }^{2}$ The pivotal role of education as a socialisation, liberation and developmental force indicates that an acceptable 'right to education' should be complemented by 'rights in education'. ${ }^{13}$ Rights in education require 'protection of and respect for learners' cultures, needs and languages'.14

This article will examine postcolonial theories as well as the historicity of African education and argue for the possibility of decolonising education. For the purposes of the article, education refers to 'organized activities that take place in schools that are intended to transmit skills, knowledge'. ${ }^{15}$ There is a danger that African governments continue to use education as a tool of subjugation. Using the framework of international human rights law to effectively decolonise education could prevent this.

\section{Africa and postcolonial deconstruction}

Sertima describes the effects of colonialism in Africa thus:

No human disaster ... can equal in dimension of destructiveness the cataclysm that shook Africa ... the threads of cultural and historical continuity were so savagely torn asunder that henceforward one would have to think of two Africas: the one before and the one after the Holocaust. ${ }^{16}$

The consequence of the colonial encounter between Europe and Africa was to establish thereafter the parameters for global power and the gateway of acceptable language, knowledge, jurisprudence and thought. ${ }^{17}$ The colonial relationship functioned through acculturation mechanisms such as 'assimilation' and 'association', predicated on presumed African inferiority; these mechanisms were justified by treaties that disempowered and fervent evangelising, as well as arguments that alluded to both imperial profit-making and humanitarian munificence. ${ }^{18}$ Mbembé states that colonisation was an enterprise of appropriation, familiarisation and utilisation. ${ }^{19}$ The overall result was to effectively silence African history, knowledge and autonomy. ${ }^{20}$

Postcolonial theory analyses the consequences of colonialism on the colonised. Theorists consider the ideas of hierarchical difference in how the image of Africa is

11 Gayatri Chakravorty Spivak, 'Can the Subaltern Speak?' in Cary Nelson and Lawrence Grossberg (eds), Marxism and the Interpretation of Culture (Macmillan Education UK 1988) 271-313.

12 Paulo Freire, Pedagogy of the Oppressed, Myra Bergman Ramos (trans) (Continuum 2000).

13 Zehlia Babaci-Wilhite et al, 'Education and Language: A Human Right for Sustainable Development in Africa' (2012) 58(5) International Review of Education 628.

14 Ibid 629.

15 Ali A Abdi and Ailie Cleghorn, 'Sociology of Education: Theoretical and Conceptual Perspectives' in Abdi and Cleghorn (n 5) 5 .

16 Ivan van Sertima, Black Women in Antiquity (Transaction Books 1984) 8.

17 Anghie (n 5) 66.

18 Ibid 206; Walter Rodney, How Europe Underdeveloped Africa (Bogle-L'Ouverture Publications 1972) 247; Dismao A Masolo, 'African Philosophers in the Greco-Roman Era' in Kwasi Wiredu (ed), A Companion to African Philosophy (Blackwell 2004) 51; Edward Shizha, 'Rethinking and Reconstituting Indigenous Knowledge and Voices in the Academy in Zimbabwe: A Decolonization Process' in Dip Kapoor and Edward Shizha (eds), Indigenous Knowledge and Learning in Asia/Pacific and Africa: Perspectives on Development, Education, and Culture (Palgrave Macmillan 2010) 118; Nyamnjoh (n 5) 132.

19 Achille Mbembé, On the Postcolony (University of California Press 2001) 237.

20 Olivia Rutazibwa, 'Studying Agaciro: Moving beyond Wilsonian Interventionist Knowledge Production on Rwanda' (2014) 8(4) Journal of Intervention and Statebuilding 294; Shizha (n 5) 69. 
reproduced or represented in literature as well as new and old media. ${ }^{21}$ The idea or invention of Africa cannot be divorced from the ideology that drove colonisation - the distinction between the civilised and the uncivilised. ${ }^{22}$ That ideology pervades Africa's current relation with the rest of the world - power structures, politics, language and knowledge. Chinua Achebe, commenting on Joseph Conrad's Heart of Darkness (1899), states that the book's thesis is based on a presumption of African savagery, barbarism and intellectual inferiority. ${ }^{23}$ Edward Said's critique of Conrad notes that, despite Conrad's disgust for colonial horrors, a world where Europe did not exercise mastery over Africa was beyond Conrad's imagination. ${ }^{24}$ Postcolonial theory recognises that the incompetence and dependence of Africa's contemporary political and intellectual elite on external approval and assistance result from hybridity of supposed African authenticity and the attempted replication of colonial character, all carried out within an inherited colonial structure. $^{25}$

Postcolonialism is concerned with:

... the purely methodological question of knowing whether it is possible to offer an intelligible reading of contemporary Africa solely through conceptual structures and fictional representations used precisely to deny African societies any historical depth and to define them as radically other, as all that the West is not. ${ }^{26}$

In other words, postcolonial theory seeks to find the truth about Africa.

Ahluwalia states that even though postcolonial theory seems to have been mainly concerned with literary examination, it is helpful in 'suggesting that a polity be examined in totality from the rupturing moment of colonisation'. ${ }^{27}$ It can potentially become more than a special branch of cultural studies. Postcolonial theory recognises that 'whilst retaining its linkages to its European past ... through the process of hybridisation and transculturation, the African state has been and continues to be inflected locally'. ${ }^{28}$ However, a suitably developed theory 'offers a way to break down the tyranny of the structures of power', ${ }^{29}$ both for the individual and the state.

One of the major structures of power concerns the control of knowledge. Mudimbe and Nyamnjoh suggest that knowledge of Africa is based on three major systems anthropological science, colonial politics and the 'civilising mission'. 30 The underlying idea of difference driving these knowledge systems imbued their interactions with

21 Michael Syrotinski, Deconstruction and the Postcolonial: At the Limits of Theory (Liverpool UP 2007) 67, 83; Okwach Abagi, 'The Role of the School in Africa in the Twenty-First Century: Coping with Forces of Change' in Abdi and Cleghorn (n 5) 301; Valentin Y Mudimbe, The Invention of Africa: Prognosis, Philosophy and the Order of Knowledge (Indiana UP 1988); Valentin Yves Mudimbe, The Idea of Africa (Indiana UP 1994); Makau W Mutua, 'Savages, Victims, and Saviors: The Metaphor of Human Rights' (2001) 42(1) Harvard International Law Journal 201-45; Frantz Fanon and Constance Farrington, The Wretched of the Earth (Penguin Books 1963); Ngugi Wa Thiong'o, Decolonising the Mind: The Politics of Language in African Literature (East African Publishers 1994).

22 Syrotinski (n 21) 98; Anghie (n 5) 65.

23 Chinua Achebe, 'An Image of Africa' (1978) 9(1) Research in African Literatures 3.

24 Edward Said, Culture and Imperialism (Vintage 1994) 22-31.

25 Syrotinski (n 21) 69, 70, 72, 76, 99; Christopher Clapham, Africa and the International System: The Politics of State Survival (CUP 1996) 32; Nyamnjoh (n 5) 134.

26 Mbembé (n 19) 11.

27 Pal Ahluwalia, Politics and Post-Colonial Theory: African Inflections (Routledge 2012) 14.

28 Ibid 66.

29 Ibid 72.

30 Mudimbe, Invention of Africa (n 21) 14-36; Nyamnjoh (n 5) 130. 
practices of acculturation. ${ }^{31}$ The systems are supported by what Mudimbe calls the 'colonial library' - the epistemology of supposed knowledge of Africa - a system of thought so ingrained in our consciousness that we argue against its theories by referencing its precepts. ${ }^{32}$ Mudimbe's arguments are reminiscent of Foucault, though Mudimbe is aware of his own self-contradictions. ${ }^{33}$ Syrotinski translates a metaphor of an African researcher from Mudimbe's 'L'autre Face du Royaume', 'who rides up and down a lift believing that he or she is in control of its movement, all the while unaware that Western technicians in fact possess the knowledge of its operation and thus ultimately determine the limits of its freedom'. ${ }^{34}$ Harrow says of Mudimbe's arguments, that the retreat from colonialism 'must transcend the limits imposed on the situation by the refusal of its givens altogether, 35 questioning the possibility of transcending international life. Mudimbe ultimately realises that we cannot speak of decolonisation without understanding the psychology of colonisation; yet decolonisation cannot achieve a return to precolonial Africa because acculturation is also a fact of history not particular to Africa. ${ }^{36}$ Therefore, formal education cannot be wholly replaced by indigenous knowledge, decolonisation should point forwards, not backwards. Deconstructive reading of postcolonial theory aids this possibility.

Deconstruction has as one of its main authors Jacques Derrida. Derrida sought to question assumptions within Western thought by challenging the premises of stasis and rationality upon which Western philosophy is based. ${ }^{37}$ Deconstruction explores accepted assertions to find other meanings than the one constructed: the idea of truth suggests the possibility of fiction, the idea of justice suggests the possibility of injustice. ${ }^{38}$ Language, and consequently the world, is shown to be figurative; objectivity can be questioned as it is constructed through unreliable language. Deconstruction asks us to look beyond the text or the 'representation' and question the normalisation of the construction of Africa, enabling us to rewrite/reinvent Africa, to de-victimise Africa, to iterate Africa in the context of a possible equal future. ${ }^{39}$ Deconstruction is of particular relevance to epistemic violence, which is concerned with dominant knowledge that silences other forms of knowledge; it is the cognitive inability to engage with the truth of another group's social experience. ${ }^{40}$

'Deconstructive post-colonialism' as theorised by Syrotinski is a scholarly process that can potentially reduce the perceived political inefficacy of deconstruction and grant postcolonialism political force. ${ }^{41}$ Syrotinski contends that 'deconstruction as a highly

31 Mudimbe, Invention of Africa (n 21) 33; Anghie (n 5) 65.

32 Mudimbe, Invention of Africa (n 21) 179-94; Hallen, African Philosophy (n 5) 44.

33 Mudimbe, Invention of Africa (n 21) 56.

34 Syrotinski (n 21) 85.

35 Kenneth Harrow, 'Mudimbe and the Power of the Word' in Stephen Arnold (ed), African Literature Studies: The Present State (Cornell UP 1985) 97.

36 Mudimbe, Invention of Africa (n 21) 167, 168, 209; Bryan Mukandi, 'Chester Himes, Jacques Derrida and Inescapable Colonialism: Reflections on African Philosophy from the Diaspora' (2015) 34(4) South African Journal of Philosophy 535.

37 Jacques Derrida, Writing and Difference (University of Chicago Press 1978) especially 41; Barry Stocker, Routledge Philosophy Guidebook to Derrida on Deconstruction (Routledge 2006) 107, 115-16, 188-9.

38 Michael Syrotinski, 'Monstrous Fictions: Testifying to the Rwandan Genocide in Tierno Monénembo's L'ainé des Orphelins' (2009) 45(4) Forum for Modern Language Studies 437; Jack M Balin, 'Deconstructive Practice and Legal Theory' (1987) 96(4) Yale Law Journal 743-86.

39 Syrotinski (n 21) 74, 109, 111-13, 115.

40 Miranda Fricker, Epistemic Injustice: Power and the Ethics of Knowing (OUP 2007) 152-69.

41 Syrotinski (n 21) 23, 118. 
vigilant reading practice, can inform our critical understanding of specific post-colonial contexts'. ${ }^{42} \mathrm{He}$ argues for a closer theoretical relationship between postcolonial theory and deconstruction. Syrotinski maintains that Mbembé's thesis of 'writing Africa' engages 'in a deconstructive mode of reading that responds to the imperative of a "writing of the disaster". 43 He goes on to state that deconstruction teaches us that the historical instances of African trauma 'are the very condition of the possibility of writing and reading narratives ... and the post-colonial'. ${ }^{4}$ Or, as Mbembé himself suggests, 'each death or defeat leads to a new appearance, is perceived as confirmation, gage, and relaunch of an ongoing promise, a "not yet," a "what is coming," which - always separates hope from utopia'. 45 Postcolonialism points forward, not with an unshakeable narrative of fatality, but with a narrative of equal freedom and opportunity. Syrotinski states that 'the work of remembering and mourning is an ongoing collective responsibility, and not simply a civic duty we perform so as to then forget'. 46 Deconstructing the postcolonial speaks of what can be, despite the trauma of colonialism and the incapacity of the postcolonial state.

\section{Africa, the right to education and Freire's pedagogy}

In Africa, the right to education is protected by a collection of international, regional and national legislation, but most specifically by Articles 13 and 14 of the International Covenant on Economic, Social and Cultural Rights (ICESCR). Protections within regional laws merely reiterate the ICESCR. According to the Committee on Economic, Social and Cultural Rights (CESCR), education is a means of attainment of all other rights. ${ }^{47}$ The UN Committee on the Rights of the Child states that education should reflect a balance between promoting the physical, mental, spiritual and emotional aspects and the intellectual, social and practical dimensions of education. ${ }^{48}$ The right to education has been described as an empowerment right or a gateway right. ${ }^{49}$ Consequently, the right should enable the educated to take control of her life and contribute to the development of her state. ${ }^{50}$

In its General Comment No 13, the CESCR provides that primary education should be free and quality education should be available, accessible, acceptable and adaptable. ${ }^{51}$ Coupled with quantitative data, such as the ratio of a state's youth in education and the portion of state resources allocated to education, the foregoing features provide a standard assessment of education. ${ }^{52}$ Process and outcome indicators are used to

42 Ibid 59.

43 Ibid 118.

44 Ibid 123.

45 Mbembé (n 19) 206.

46 Syrotinski (n 38) 12.

47 CESCR General Comment No 13: The Right to Education (Article 13), 8 December 1999, E/C12/1999/10; Fons Coomans, 'Clarifying the Core Elements of the Right to Education' (1988) 10 Framework 215.

48 UN Committee on the Rights of the Child, General Comment No 1 (2001), Article 29(1): The Aims of Education, CRC/GC/2001/1, para 12.

49 Klaus D Beiter, The Protection of the Right to Education by International Law (Brill 2005) 56.

50 Coomans (n 47) 214.

51 CESCR (n 47); Sital Kalantry, Jocelyn E Getgen and Steven Arrigg Koh, 'Enhancing Enforcement of Economic, Social, and Cultural Rights Using Indicators: A Focus on the Right to Education in the ICESCR' (2010) 32(2) Human Rights Quarterly 278.

52 Katrien Beeckman, 'Measuring the Implementation of the Right to Education: Educational versus Human Rights Indicators' (2004) 12(1) International Journal of Children's Rights 72, 73, 77. 
determine the suitability of laws and policies and, consequently, the resulting effect of these laws and policies. ${ }^{53}$

According to UNESCO, sub-Saharan African states are comparatively behind other regions in the provision of education. ${ }^{54}$ In 2012 sub-Saharan Africa had the lowest regional gross enrolment ratio - 20 per cent. North America and Western Europe's ratio stood at 89 per cent and Central Asia's at 33 per cent. Provision of early childcare in subSaharan Africa stood at 20 per cent - unfavourably compared to Latin America at 74 per cent. Sub-Saharan Africa also had the highest regional numbers of students not in school - at nearly 30,000, almost three times Asian regional numbers. Attainment of literacy skills also suffers as education systems exhibit infrastructural failures in access and learning. ${ }^{55}$ The inadequacies of the education system are played out against a background of high child-marriage rates, parent illiteracy, poverty and political unrest. ${ }^{56}$

While some regional legal instruments attempted to include 'African values' within their standards, ${ }^{57}$ these have failed to be effective as they are attached to legal norms that seem to be in direct contradiction to those propositions. Nevertheless, scholars like Mutua and An-Na'im argue that, without the inclusion of the African perspective in international human rights law (IHRL), the human rights mosaic is incomplete and undemocratic. ${ }^{58}$ IHRL is naturally suspicious of tradition, but if our desire to improve human rights and education is predicated on the inherent value of all human experience, we cannot justly disregard a significant part of that experience in doing so. To achieve universality (and not uniformity) of human rights, a more multifaceted conception of how human rights norms are assimilated by different cultures needs to be attained. Culture could in essence be appropriated as a functional tool to help in the promotion and entrenchment of human rights. ${ }^{59}$ Indigenisation of education measures in Canada, Australia and the Philippines was followed by an increase in student representation from

53 Kalantry et al (n 51) 282.

54 UNESCO, 'Education for All 2000-2015: Achievements and Challenges' (UNESCO 2015) <http://unesdoc.unesco.org/images/0023/002322/232205e.pdf >.

55 Kevin Watkins, 'Too Little Access, not Enough Learning: Africa's Twin Deficit in Education' in This is Africa Special Report, Access+: Towards a post-MDG Development Agenda on Education (2013) $<$ www.brookings.edu/research/opinions/2013/01/16-africa-learning-watkins>; Amina Mama, 'Is It Ethical to Study Africa? Preliminary Thoughts on Scholarship and Freedom' (2007) 50(1) African Studies Review 22; Africa-America Institute, State of Education in Africa Report 2015: Overview of the State of Education in AfricaEarly Childhood, Primary and Secondary Education, Vocational and Technical Training, and Higher Education (2015) 6-11: <www.aaionline.org/wp-content/uploads/2015/09/AAI-SOE-report-2015-final.pdf>; Justin W Van Fleet, K Watkins and L Greubel, 'Africa Learning Barometer' (2012) 1-14: <www.brookings.edu/ /media/events/2012/9/17-africa-learning/africa-learning-barometerfinal.pdf>; Brendalyn P Ambrose, Democratization and the Protection of Human Rights in Africa: Problems and Prospects (Greenwood Publishing Group 1995) 67; Abagi (n 21) 301; Birgit Brock-Utne and Malcolm Mercer, 'Languages of Instruction and the Question of Education Quality in Africa: A Post-2015 Challenge and the Work of CASAS' (2014) 44(4) Compare: A Journal of Comparative and International Education 677.

56 Watkins (n 55); Nyamnjoh (n 5) 139; Abagi (n 21) 302-5.

57 African Charter on Human and People's Rights (ACHPR), Articles 27-29.

58 Makau Wa Mutua, 'The Banjul Charter and the African Cultural Fingerprint: An Evaluation of the Language of Duties' (1994) 35 Virginia Journal of International Law 344; Abdullahi A An-Na'im, 'Problems of Universal Cultural Legitimacy for Human Rights' in Abdullahi A An-Na'im and Francis Deng (eds), Human Rights in Africa: Cross-Cultural Perspectives (Brookings Institution Press 1990) 339; Charles R Beitz, 'Human Rights as a Common Concern' (2001) 95 American Political Science Association 270.

59 Jack Donnelly, Universal Human Rights in Theory and Practice (Cornell UP 2013) 112; Manfred O Hinz, 'Human Rights between Universalism and Cultural Relativism? The Need for Anthropological Jurisprudence in the Globalising World' in Anton Bösl and Joseph Diescho (eds), Human Rights in Africa: Legal Perspectives on their Protection and Promotion (Konrad Adenauer Foundation 2009) 3, 12. 
marginal groups, a new understanding of citizenship and a more robust curriculum. ${ }^{60}$ Freire's ideas about 'situationality' therefore have proven merit. ${ }^{61}$

Paulo Freire was a Brazilian educator whose ideas on pedagogy are encapsulated succinctly in his book The Pedagogy of the Oppressed (1968). Freire argued that education was usually structured as a system of knowledge 'banking' - collection and regurgitation that dehumanises the subject. ${ }^{62}$ This is reflected in ethnographies conducted in Kenya which showed that, despite code-mixing, the use of English as the primary language of instruction resulted in ritualistic use of language and limited epistemological access. ${ }^{63}$ Furthermore, studies in post-apartheid South Africa have suggested that memorisation takes precedence over inquiry. ${ }^{64}$ Freire contended that knowledge is formed and reformed through persistent human inquiry about the world. ${ }^{65} \mathrm{He}$ asserted that education should transcend understanding the world to encompass changing the world; education should transform and empower participants, not make them conform to prototypical representation. ${ }^{66}$ He was a firm believer that education should reflect the lived experiences of participants in education - their 'situationality'. ${ }^{67}$ To achieve these aims, Freire argued that the 'oppressed' have to 'unveil the world of oppression' themselves. This can be done through an equal relationship of dialogue so that education 'expresses the consciousness' of the teachers and students. ${ }^{68} \mathrm{He}$ recognised that anticolonial leaders may step into the shoes of the colonisers and use education to silence, in a similar fashion to their predecessors. ${ }^{69}$ Silence and freedom, he stressed, are a contradiction. ${ }^{70}$ Freire understood that education had revolutionary capacities and could be used to change the course of history $;^{71}$ in this he mirrors postcolonial deconstruction's thesis of possibility through education.

His work has had particular significance for pedagogical reform in the African countries of Guinea-Bissau, Egypt and Kenya; ${ }^{72}$ his pedagogy is especially relevant for rural Africa where illiteracy is high. ${ }^{73}$ While it has been argued that his language is impenetrable, his theories appear to resonate more deeply with people who are subject to

60 Mishack T Gumbo, 'A Model for Indigenising the University Curriculum: A Quest for Educational Relevance' in Vuyisile Msila and Mishack T Gumbo (eds), Africanising the Curriculum: Indigenous Perspectives and Theories (Sun Media Metro 2016) 39, 46-8.

61 Freire (n 12) 109.

62 Ibid 72 .

63 Grace Bunyi, 'Language Classroom Practices in Kenya' in Angel Lin and Peter W Martin (eds), Decolonisation, Globalisation: Language-in-Education Policy and Practice (Multilingual Matters 2005) 132-50.

64 Meshach B Ogunniyi, 'Cultural Perspectives on Science and Technology Education' in Abdi and Cleghorn (n 5) 127.

65 Freire (n 12) 72.

66 Ibid 25, 34, 45, 47.

67 Ibid 54, 95, 109.

68 Ibid 54, 68-9, 88, 95.

69 Ibid 68,89 .

70 Ibid 89.

71 Ibid 84

72 Karl Botchway, 'Paradox of Empowerment: Reflections on a Case Study from Northern Ghana' (2001) 29(1) World Development 135-53; Osman A Ahmed et al, 'A Reflection on the Works of Paulo Freire and its Relevance to Classroom Teaching' (2014) 13 Middle Eastern and African Journal of Educational Research 21; Heba Sharobeem, 'The Impact of the Arab Spring at an Egyptian University: A Personal Experience' (2015) 4 Middle East-Topics and Arguments 110-21.

73 Juma E Nyirenda, 'The Relevance of Paulo Freire's Contributions to Education and Development in Present Day Africa' (1996) 10(1) Africa Media Review 19. 
hierarchical structures of knowledge. ${ }^{74}$ Nevertheless, any adoption of a Freirian approach needs to be adaptable to the needs of any population in the twenty-first century. Knowledge is fluid. As Nyamnjoh states, to transcend epistemological blindness, 'we must not define and confine Africa a priori, racially, geographically or otherwise'. ${ }^{75}$

\section{Conceptual limitations to researching the right to education in Africa}

In researching the implementation of the right to education, the individual right-holder should be the focus of attention. However, postcolonial deconstruction posits that the incomplete ideological construction of Africa is a result of filling the cracks of the unknown with the known. ${ }^{76}$ Because Africa was unknown, African 'things' had to be signs of a prior stage of evolution resulting in a denial of previous undocumented historicity. ${ }^{77}$ All theorising about Africa extends from our 'knowledge' of Africa as not existing before colonialism, an Africa without political or social structures, without history, literature or philosophy, without art or science, an Africa without education. ${ }^{78}$ Our discussions of Africa are ultimately and persistently concerned with social engineering. ${ }^{79}$ Freire engages with this by predicating his ideas on trust and humanism. He says:

No pedagogy which is truly liberating can remain distant from the oppressed by treating them as unfortunates and by presenting for their emulation models from among the oppressors. The oppressed must be their own example in the struggle for their redemption. ${ }^{80}$

Current epistemology is derived in an unbroken line of pedagogy from the precolonial to the postcolonial and used to explain all current African phenomena. ${ }^{81}$ Therefore, current implementation of the right to education ignores the fact that mimicry of cultural ideology will never become mastery, notwithstanding sincerity of the mimic or the master. ${ }^{82}$ As Shizha states: 'Mental or psychological colonization was conducted through, among other mechanisms, Western education, texts, and literature'. ${ }^{83}$ Defetishising, deconstructing and reconstructing our view of Africa moves us beyond the idea of an immutable dialectic sequence of African instability 84 and averts our gaze from the trauma to individuals. Without acknowledging the wounds of colonialism, healing is impossible 85 and our gaze is incomplete. ${ }^{86}$ Our understanding of African crises is reflexively attributed to our construction of Africa as an 'absolute other'; our gaze of Africa is seen through its representations rather than its substantiation or any engagement with African humanity or the subjects' lived experiences; these representations confine our collective

74 Freire (n 12) 23.

75 Nyamnjoh (n 8) 82.

76 Syrotinski (n 21) 68; Samuel O Imbo, 'Okot p'Bitek's Critique of Western Scholarship on African Religion' in $\mathrm{K}$ Wiredu (ed), A Companion to African Philosophy (Wiley 2008) 371.

77 Syrotinski (n 21) 68, 77; Hallen, African Philosophy (n 5) 102.

78 Pierre Englebert, 'Feature Review - The Contemporary African State: Neither African nor State' (1997) 18(4) Third World Quarterly 767.

79 Mbembé (n 19) 7.

80 Freire (n 12) 84.

81 Mbembé (n 19) 3; Syrotinski (n 21) 79, 83.

82 Mbembé (n 19) 25; Syrotinski (n 21) 78; Hallen, African Pbilosophy (n 5) 38; Fanon and Farrington (n 21 ) 312.

83 Shizha (n 18) 119.

84 Syrotinski (n 21) 122.

85 Ibid 69.

86 Chimamanda N Adichie, 'The Dangers of a Single Story' (Tedtalks 2009) < www.ted.com/talks/chimamanda_ adichie_the_danger_of_a_single_story.htm $>$. 
memory to one of absolute night, forgetting the existence or possibility of sunrise. ${ }^{87}$ Thus academic research ignores the African subject in favour of the 'African project'. ${ }^{88}$ This is evidenced by research collection in Africa by non-African academics which is imbued with preconceived representations of Africa and thus focuses on aims congruent with the research agenda but incongruent with the needs of the researched. ${ }^{89}$

While the idea of IHRL, and thus the right to education, is underpinned by the equality of the human subject, its implementation is powered by the hierarchical nature of otherness and consequently knowledge. Anghie makes a powerful argument for the colonial origins of international law, predicated on the disempowering nature of the idea of difference. ${ }^{90}$ Otherness, in this sense, differs from particularity - otherness implies difference centred on inferiority; particularity acknowledges individuality and the human dignity of the subject.

The African is torn between a past lost in the mists of time and the fear of losing herself in a modern future constructed on an exogenous template. ${ }^{91}$ This creates a dilemma from which there is apparently no possible escape: the African cannot be known without the tools of education, yet this education dilutes the authenticity of past experience and makes the knowing superficial. Lorde says: 'the master's tools will never dismantle the master's house'. ${ }^{2}$ So modernity cannot be obtained without the African giving away part of her soul; Kingsley suggested that the philanthropist killed the African's soul to save the African's life. ${ }^{93}$ Reconceptualising Africa envisions the possibility of implementing the right to education in Africa without killing the African soul; 'situationality' takes up indigenous tools to decolonise education, preventing reproduction of colonial ideas. ${ }^{94}$ By understanding that our knowledge of Africa is subjective and continually open to contestation, we can explore the performances within languages, international law, history and legal arguments. ${ }^{95}$ Acknowledging epistemic injustice recognises the ethical and unethical purposes of education in Africa's history.

\section{The history of education in Africa}

Assessment of educational attainment is focused on standards set by the international community and is concerned with postcolonial structures of formal schooling. ${ }^{96}$ These assessments do not consider decolonisation, or the suitability of the existing education structure for the region, reducing education's effectiveness as a tool for social development. ${ }^{97}$ History was removed from Nigeria's core syllabus in the 1970 s, producing

87 Mbembé (n 19) 6, 241-2; Syrotinski (n 21) 99; Syrotinski (n 38) 4, 8.

88 Mbembé (n 19) 7-8.

89 Richard A Shweder, “What about 'Female Genital Mutilation”? And Why Understanding Culture Matters in the First Place’ (2000) 129 Daedalus 209, 213.

90 Anghie (n 5) 312.

91 Mbembé (n 19) 12; Abagi (n 21) 311.

92 Audre Lorde, Sister Outsider: Essays and Speeches (Crossing Press 2012) 110-13.

93 Quoted in Joseph Ephraim Casely Hayford, The Truth about the West African Land Question (Psychology Press 1971) 6.

94 Anghie (n 5) 313.

95 Ibid 320; Mudimbe, Invention of Africa (n 21) 193.

96 Report of the Special Rapporteur on the Right to Education, Kishore Singh: Assessment of the Educational Attainment of Students and the Implementation of the Right to Education A/HRC/26/27.

97 Ambrose (n 55) xvii; Nyamnjoh (n 5) 138; Abdullahi An-Na’im, 'Cultural Transformation and Normative Consensus on the Best Interests of the Child' (1994) 8(1) International Journal of Law, Policy and the Family 74. 
a generation ignorant of its own history. ${ }^{98}$ In most African states education is conducted in a colonial language. ${ }^{99}$ According to Namukasa, the school structure and taught content in Uganda has changed little since independence from Britain in 1962.100

The quality of colonial education was intentionally poor. ${ }^{101}$ Spending on education was low and European powers spent considerably more on education in their own states. ${ }^{102}$ In 1935 in Nigeria, only 3.4 per cent of colonial tax was spent on education. ${ }^{103}$ The distribution of schools reflected the areas exploited for agricultural produce - the more agricultural produce extracted in an area by the colonial powers, the more likely it would be to find schools; access was restricted for Africans. ${ }^{104}$ The content of education will reflect the purposes of education; the purpose of colonial education was to stifle resistance, provide local support staff who could communicate in the required European language and elevate a select few. ${ }^{105}$ This created incongruity of content, as Rodney notes:

On a hot afternoon in some tropical African school, a class of black shining faces would listen to their geography lesson on the seasons of the year - spring, summer, autumn, and winter. They would learn about the Alps and the river Rhine but nothing about the Atlas Mountains of North Africa or the river Zambezi. If those students were in a British colony, they would dutifully write that 'we defeated the Spanish Armada in 1588' . . . If they were in a French colony, they would learn that 'the Gauls, our ancestors, had blue eyes', and they would be convinced that 'Napoleon was our greatest general . ..'106

This was in contrast to precolonial communities that thrived on oral traditions, telling generational legends in the humid moonlight, helping to preserve a sense of community, connectivity and continuity. ${ }^{107}$ Such communities had a heavy cultural dependence on musical (and mostly legislative) proverbs and lyrical poetry. ${ }^{108}$ The colonial education system introduced non-lyrical European languages and the written text; these are more detached, causing a socio-cultural rift in the communicative space. Consequently, many Africans write fluently only in a European language, but speak one or more African languages fluently. This greatly impedes the learning process. ${ }^{109}$ The learner is simultaneously struggling with language and text leading to false and slow translations

98 Odunyemi O Agbelusi, 'Archaeological Education in Nigeria: Concepts, Methods, Challenges, and Recommendations' (2015) 11(2) Archaeologies 223.

99 Ali A Abdi, 'Clash of Dominant Discourses and African Philosophies and Epistemologies of Education' in Abdi (n 6) 137.

100 Immaculate K Namukasa et al, 'Critical Curriculum Renewal in Africa' in Abdi (n 6) 179, 182.

101 Rodney (n 18) 246; Roland Oliver and Anthony Atmore, Africa since 1800 5th edn (CUP 2005) 146-7.

102 Ambrose (n 55) xvii.

103 Rodney (n 18) 241-2; Ewout H P Frankema, 'The Origins of Formal Education in Sub-Saharan Africa: Was British Rule more Benign?’ (2012) 16(4) European Review of Economic History 353.

104 Rodney (n 18) 243-44.

105 Nyamnjoh (n 5) 135; Shizha (n 5) 70.

106 Rodney (n 18) 247.

107 Ali A Abdi, 'Clash of Oralities and Textualities: The Colonization of the Communicative Space in SubSaharan Africa' in Kapoor and Shizha (n 18) 149; Lantana M Usman, 'The Indigenous Knowledge System of Female Pastoral Fulani of Northern Nigeria' in Kapoor and Shizha (n 18) 223.

108 Abdi (n 107) 151-2; Usman (n 107) 217; Coleman Agyeyomah et al, "To Die is Honey, and to Live is Salt": Indigenous Epistemologies of Wellness in Northern Ghana and the Threat of Institutionalized Containment' in Kapoor and Shizha (n 18) 254-8.

109 Babaci-Wilhite et al (n 13) 628. 
from thought to writing and back to thought. ${ }^{110}$ African literature students will learn more Shakespeare than Soyinka, more Wallace than Wa Thiong'o.

Pierre Forcin, a French colonial administrator, believed that to ensure the continual loyalty of the colonies it was essential that they 'remain French in language, thought and spirit'. ${ }^{111}$ Consequently, there has been focus on English, French and Portuguese as languages of instruction and national communication and also the disappearance of African languages and customs - languages that sustain a people's worldview. ${ }^{112}$ Students were also encouraged to adopt European names. ${ }^{113}$ These practices became a useful tool of colonial domination; ${ }^{114}$ the ability to speak a colonial language influenced the measure of success attainable for Africans. ${ }^{115}$

These practices have had severe consequences for African education and society. It is suggested that 20 per cent of Africans have a European language as their first language. ${ }^{116}$ Adegbija notes: 'Over $90 \%$ of African languages . . . exist as if they don't really exist; they live without being really alive. Living functional blood is being sucked out of them . . .'117 The linguistic dichotomy that occurs in Africa is exacerbated by the fact that perfect translations from indigenous languages are presumed. ${ }^{118}$ Yet all intra-African governmental meetings are carried out using a European language, irrespective of fluency. ${ }^{119}$ The language-in-education debate has economic and political implications, yet retention of colonial languages may sacrifice learning outcomes ${ }^{120}$ and may be predicated on a colonial myth of an insurmountable mass of languages. ${ }^{121}$ Though South Africa constitutionalised the equity of its multitude of languages, in practice, African languages exist at the bottom of the hierarchical communicative space. ${ }^{122}$ Therefore, while education may be physically available and accessible, the learner suffers a deficit in epistemological access and availability, resulting in pedagogically unsound learning at a high psychological cost. ${ }^{123}$ Spivak argues that colonialism is the clearest example of epistemic violence ${ }^{124}$ - the stripping of African learners of voice and language.

110 Shizha (n 5) 79.

111 Rodney (n 18) 259.

112 Abdi (n 99) 137.

113 Rodney (n 18) 247; Shizha (n 5) 69.

114 Abdi (n 107) 160; Rodney (n 18) 256; Babaci-Wilhite et al (n 13) 623, 628; Mbembé (n 19) 31.

115 Clapham (n 25) 32, 78; Abagi (n 21) 298.

116 Abdi (n 107) 159.

117 Efurosibina Adegbija, 'Saving Threatened Languages in Africa: A Case Study of Oko' in Joshua A Fishman (ed), Can Threatened Languages Be Saved? (Multilingual Matters 2001) 284; Herman Batibo, Language Decline and Death in Africa: Causes, Consequences, and Challenges (Multilingual Matters 2005) 26-27.

118 Hallen, The Good, the Bad (n 5) 35; A G A Bello, 'Some Methodological Controversies in African Philosophy' in K Wiredu (ed), A Companion to African Philosopby (Wiley 2008) 269-270.

119 Nyamnjoh (n 5) 140-1.

120 Ailie Cleghorn, 'Language Issues in African School Settings: Problems and Prospects in Attaining Education for All' in Abdi and Cleghorn (n 5) 103-5, 107, 113.

121 Birgit Brock-Utne, 'Language-in-Education Policies and Practices in Africa with a Special Focus on Tanzania and South Africa - Insights from Research in Progress' in Angel Lin and Peter W Martin (eds), Decolonisation, Globalisation: Language-in-Education Policy and Practice (Multilingual Matters 2005) 176.

122 Nkonko M Kamwangamalu, 'A New Language Policy, Old Language Practices: Status Planning for African Languages in a Multilingual South Africa' (2000) 20(1) South African Journal of African Languages 55.

123 Vitallis Chikoko, 'Issues in Africanising Higher Education Curricula' in Msila and Gumbo (n 60) 72-3; BrockUtne (n 121) 180.

124 Spivak (n 11) 280-1. 
Currently, speaking indigenous languages is banned in most African schools. ${ }^{125}$ Many textbooks are imported or written in a European language; in Eritrea, education was in English and about the world outside Africa. ${ }^{126}$ Knowledge in textbooks is considered paramount and unquestionable. ${ }^{127}$ Tests that assess students' literacy do not consider problems arising from secondary fluency, as these are done in European languages. ${ }^{128}$ Someone who is perfectly able to count in her own language would be assessed as having poor numeracy skills in a language she is very unfamiliar with. In many African societies, the language of instruction is rarely used at home and may be inadequately understood by the teacher. ${ }^{129}$ Quality education suggests that education should be done in a language that is understood by both the learner and the teacher; ${ }^{130}$ alternatively, code-switching and code-mixing should be adopted. ${ }^{131}$ Nelson Mandela said: 'If you talk to a man in a language he understands, that goes to his head. If you talk to him in his language . . that goes to his heart'. ${ }^{132}$ For education to be a useful tool of individual and national development, it has to do more than go to the mind. It has to be transformative. ${ }^{133}$

Indigenous knowledge about agriculture, healing and dietary herbs, medicinal practices, societal values, as well as farming systems and artisan communities was swept away by colonial education. ${ }^{134}$ Skills considered to be of great significance to an indigenous community, e.g. the language of the drums, bone-setting and knowledge of medicinal herbs, have been lost. 135 Prior to colonisation, there had been different ways of acquiring knowledge in and of Africa, but these were replaced and forgotten. ${ }^{136}$ Indigenous knowledge has the potential for increasing global knowledge of agriculture, ecology, politics, sociology and the arts, among others. ${ }^{137}$ Implementing the rights to democracy, environment and development may depend on including indigenous knowledge in the framework of global thought. Research tools and methods can be improved by investigating indigenous knowledge. ${ }^{138}$

Therefore postcolonial education ideologically dislocates individuals from their society and, due to limited literacy and numeracy, does not equip them for any other. ${ }^{139}$

125 Nyamnjoh (n 5) 140; Shizha (n 5) 79.

126 Robert G David, 'Eritrean Voices: Indigenous Views on the Development of the Curriculum Ten Years after Independence' 24(4) International Journal of Educational Development 440-1.

127 Karen L Biraimah, 'Moving beyond a Destructive Past to a Decolonised and Inclusive Future: The Role of Ubuntu-style Education in Providing Culturally Relevant Pedagogy for Namibia' (2016) 62(1) International Review of Education 55 .

128 Brock-Utne and Mercer (n 55) 677.

129 Ibid.

130 Ibid 679.

131 Cleghorn (n 120) 109-12.

132 BBC Learning English - Moving Words: 'Nelson Mandela': <www.bbc.co.uk/worldservice/learningenglish/ movingwords/shortlist/mandela.shtml $>$.

133 Nyamnjoh (n 5) 133-4.

134 Shizha (n 18) 118; Shizha (n 5) 68; Usman (n 107) 218-23; Njoki N Wane, 'Traditional Healing Practices: Conversations with Herbalists in Kenya' in Kapoor and Shizha (n 18) 231, 233; Agyeyomah et al (n 108) 245-59.

135 Adebisi Arewa, 'The Humanist Basis of African Communitarianism as Viable Third Alternative Theory of Developmentalism' in Oche Onazi (ed), African Legal Theory and Contemporary Problems (Springer Netherlands 2014) 250; Hallen, The Good, the Bad (n 5) 6.

136 Shizha (n 18) 119; Shizha (n 5) 67.

137 Nkosinathi Mkosi, 'Surveying Indigenous Knowledge, the Curriculum and Development in Africa: A Critical African Viewpoint' in Abdi and Cleghorn (n 5) 92.

138 Ibid 93.

139 Rodney (n 18) 246, 249; Shizha (n 18) 119; Babaci-Wilhite et al (n 13) 630; Shizha (n 5) 67, 74; Nyamnjoh (n 5 ) $133,141$. 
The prestige of education becomes the end of education and its only purpose. ${ }^{140}$ Indigenous knowledge is based on a cultural worldview and forms a core of an individual's identity and connection to her community. ${ }^{141}$ Colonised education results in a citizenry with low civil affinity to the state and little technological knowhow, depriving African states of the right to democracy and development. ${ }^{142}$ The effect of ideological dissonance is such that the physical is preserved but identity is destroyed; existence replaces living, existence is dehumanised. ${ }^{143}$

\section{Postcolonial African CURRICULUM REFORMS}

Due to the foregoing limitations of colonial education, there have been several postcolonial curriculum reforms. These attempted to reflect the thoughts of local communities and respond to continental issues. ${ }^{144}$ In Tanzania, Nyerere introduced a Freire-inspired farm-school system. ${ }^{145}$ In 1995, South Africa included indigenous knowledge in its redesign of the curriculum. ${ }^{146}$ UNESCO also backed a programme which seeks to provide inclusive education across Africa. ${ }^{147}$ However, reforms have found it difficult to balance internationalisation with Africanisation; ${ }^{148}$ it has also proved difficult to combat resistance based on the belief that indigenisation is 'dumbingdown'. ${ }^{149}$ Due to the nature of anticolonial struggles, postcolonial initiatives immediately following independence were characterised by an uncomfortably close relationship between the political and the intellectual. ${ }^{150}$ Consequently, African governments have been known to stifle research aimed at redesign for politically selfish reasons. ${ }^{151}$ While in countries like South Africa, Malawi, Nigeria and Rwanda intellectuals helped to prop up dictatorial regimes, ${ }^{152}$ at other times intellectuals were at the forefront of dissent. ${ }^{153}$ Inadequate personnel and research impede continental efforts to reform curricula, ${ }^{154}$ while international efforts are uninformed, sporadic and isolated. ${ }^{155}$ The Structural Adjustment Programmes introduced to Africa by international financial institutions in the

140 Mbembé (n 19) 130.

141 Shizha (n 5) 70; Usman (n 107) 215; Agyeyomah et al (n 108) 253.

142 Ambrose (n 55) xvii; Babaci-Wilhite (n 13) 630; Shizha (n 5) 65.

143 Syrotinski (n 21) 103; Nyamnjoh (n 5) 133, 141; Mbembé (n 19) 239; Shizha (n 5) 67, 72.

144 Phillip Higgs, 'The African Renaissance and the Decolonisation of the Curriculum' in Msila and Gumbo (n 60) 8; Gregory H Kamwendo, 'Unpacking Africanisation of Higher Education Curricula: Towards a Framework' in Msila and Gumbo (n 60) 18; C T Viljoen and J L Van der Walt, 'Being and Becoming: Negotiations on Educational Identity in (South) Africa' (2003) 23(1) South African Journal Of Education 14. 145 Mayo (n 6) 47.

146 Higgs (n 144) 11.

147 Biraimah (n 127) 51.

148 Kamwendo (n 144), 21; Viljoen and Van der Walt (n 144) 15.

149 Vuyisile Msila, 'Africanisation of Education and the Search for Relevance and Context' in Msila and Gumbo (n 60) 65; Jonathan Mswazie and Tapiwa Mudyahoto, 'Africanizing the Curriculum: An Adaptive Framework for Reforming African Education Systems' (2013) 4(1) Journal of Emerging Trends in Educational Research and Policy Studies 173; Shizha (n 5) 75.

150 Mama (n 55) 9-10; Ogunniyi (n 64) 128.

151 Gumbo (n 60) 38.

152 Mama (n 55) 10.

153 Ibid 11.

154 Msila (n 149) 64.

155 Namukasa et al (n 100) 187. 
1980s and 1990s meant that governmental spending on education was greatly reduced. ${ }^{156}$ African attempts to collaborate with the West in this regard are further encumbered by comparatively higher costs of travel, difficulties in obtaining visas or visiting fellowships. ${ }^{157}$

Evidently, for educational reform to be effective it needs to be part of an equal international policy. Education on the continent has to respond to the particular issues of the continent. The power behind the universality of IHRL and the right to education can achieve this, if the 'situationality' of the educated is taken into account.

\section{'Situationality' and the purposes of education}

The accepted functions of education in all societies include developing the intellect, instilling societal norms, developing the economy, and job acquisition based on the foregoing. ${ }^{158}$ Therefore, education serves three paramount purposes - to make literate, to conform, to develop/liberate.

According to Nyamnjoh: 'Education is the inculcation of facts as knowledge and also a set of values used in turn to appraise the knowledge in question'. ${ }^{159}$ However, Africa has had no power to determine what rightly amounts to knowledge. ${ }^{160}$ Knowledge received in informal schooling structures lacks legitimacy. The worldview in formal education is so vastly dissimilar to the domestic worldview that Cleghorn describes going to school as 'crossing a cultural border'. ${ }^{161}$

Therefore, Wa Thiong'o suggests that 'a sound educational policy is one which enables students to study the culture and environment of their own society first, then in relation to the culture and environment of other societies'. ${ }^{162}$

Indigenous African knowledge has been suggested as a replacement for colonial education. Wiredu argues that conceptual decolonisation must have indigenous knowledge as its focus and not its fall-back position. ${ }^{163}$ This is utilitarian knowledge produced in response to lived experiences; it is typically idiographic knowledge transmitted orally and based on learning by 'seeing, hearing and doing' in real-life contexts. ${ }^{164}$ Indigenous knowledge is highly dependent on the specific human condition of the society in which it develops and reflective of the African worldview, thought or philosophy. ${ }^{165}$ Hallen marshals arguments which highlight the fact that resistance to the possibility of African thought shows that our paradigmatic conception of knowledge is impervious to contestation and does not take into account the prospect of plurality of thought. ${ }^{166}$ The core of education in precolonial Africa was the spiritual and intellectual

156 Yvonne Hérbert and Ali A Abdi, 'Critical Perspectives on International Education: Redefinitions, Knowledgemaking, Mobilities and Changing the World' in Ali A Abdi and Yvonne Hérbert (eds), Critical Perspectives on International Education (Sense Publishers 2013) 33.

157 Nyamnjoh (n 8) 77.

158 Watkins (n 55); Abdi and Cleghorn (n 5) 5-7.

159 Nyamnjoh (n 5) 129.

160 Syrotinski (n 21) 85.

161 Cleghorn (n 120) 106-9, 114.

162 Wa Thiong'o (n 21) 97.

163 Kwasi Wiredu, 'Introduction: African Philosophy in our Time' in $\mathrm{K}$ Wiredu (ed), A Companion to African Philosophy (Wiley 2008) 15.

164 Usman (n 107) 217, 223.

165 Ibid 223; Agyeyomah et al (n 108) 249-58; Wane (n 134) 242.

166 Hallen, African Philosopby (n 5) 69; Shizha (n 5) 69. 
development of the individual as part of a community and was based on the African worldview. ${ }^{167}$

However, due to the plurality and diversity of African culture, it is not strictly true to say that there is a single African worldview. Therefore, the African worldview is predicated on the fact that it is not singular but diverse. ${ }^{168}$ Despite this diversity there are points of convergence that suggest shared particularities between the various African worldviews. As Higgs states, accepting diverse worldviews 'acknowledges lived experience and challenges the hegemony of Western Eurocentric forms of universal knowledge'. ${ }^{169}$

The African ideology of ubuntu (mostly southern African) means humanness. ${ }^{170}$ Ubuntu is usually illustrated by the phrase 'umuntu ngumuntu ngabantu', which means 'a human being is a human being because of other human beings'. ${ }^{171}$ Ujamaa was popularised by Tanzania's Nyerere and is the idea of the 'familyhood' of African society predicated on the ideals of equality, freedom and unity. ${ }^{172}$ Umunna bu ike (Igbo/West African), 'brotherhood is power', suggests social solidarity, emphasises unity and abhors social division. ${ }^{173}$ The idea of Omolúàbi (Yoruba/West African) is that of a person defined by her good character, knowledge, humility, respect, hard work and wisdom who engages in a cyclical relationship with her community. ${ }^{174}$ The inference from the foregoing is that the African worldview is based on the cyclic concepts of 'being' and 'belonging', where 'belonging' is paramount, but to 'be' is to 'belong'. Not 'belonging' in a manner understood by indigenous thought questions the purpose of 'being'.

The acceptance of the African worldview necessarily allows us to change our image of Africa to something transformable. ${ }^{175}$ Nevertheless, proponents of the African worldview should realise that having a worldview does not preclude the possibility of contestation or change. ${ }^{176}$ This resistance to contestation has led to a tenacious and blind application of cultural values sometimes detrimental to human rights. Due to the stagnation of culture that occurred as a response to the colonial encounter and its perceived dilution of culture, anachronistic traditional views still exist. ${ }^{177}$ Therefore parts of indigenous knowledge may be incorrect, outdated and impractical to institute. ${ }^{178}$ Lack of regulation renders it unsafe to practise in isolation. ${ }^{179}$ It should be noted that the

167 Rodney (n 18) 239; Usman (n 107) 215.

168 Hallen, African Philosophy (n 5) 14.

169 Philip Higgs, 'African Philosophy and the Decolonisation of Education in Africa: Some Critical Reflections' (2012) 44(2) Educational Philosophy and Theory 51.

170 Ibid 46-7.

171 Moeketsi Letseka, 'In Defence of Ubuntu' (2012) 31(1) Studies in Philosophy and Education 48.

172 Bonny Ibhawoh and J I Dibua, 'Deconstructing Ujamaa: The Legacy of Julius Nyerere in the Quest for Social and Economic Development in Africa' (2003) 8(1) African Journal of Political Science 62; Mayo (n 6) 44, 46.

173 Kingsley N Okoro, 'African Traditional Education: A Viable Alternative for Peace Building Process in Modern Africa' (2010) 2(1) Journal of Alternative Perspectives in the Social Sciences 147; Innocent Chiluwa, 'Online Negotiation of Ethnic Identity' (Covenant University): <http://covenantuniversity.edu.ng/ content/download/34947/240636/file/online \%20negotiation $\% 20$ of $\% 20$ identity.pdf $>$.

174 K A Fayemi, 'Human Personality and the Yoruba Worldview: An Ethico-Sociological Interpretation' (2009) 9(2) Journal of Pan African Studies 167-9; O A Oyeshile, 'Traditional Yoruba Social-Ethical Values and Governance in Modern Africa' (2003) 6(2) Philosophia Africana 84; O Olufayo and L I Jegede, 'Redressing Security and Crime in Nigeria through Traditional Yoruba Social Values and Cultural Practices’ (2014) 4(4) Developing Country Studies 53.

175 Higgs (n 169) 48.

176 Ibid.

177 An-Na'im (n 97) 75.

178 Mkosi (n 137) 89.

179 Wane (n 134) 231; Agyeyomah et al (n 108) 251. 
openness to debate and discourse that Freire advocates is a cornerstone of quality education, be it in the turfed turrets of Timbuktu, the consecrated corridors of Cambridge or the hallowed halls of Harvard. Because education is a socialisation tool, ${ }^{180}$ contestation within academia will enable the worldview to evolve in line with the thinking of society, rather than setting up an exogenous worldview in eternal opposition to the endogenous one. Decolonising education cannot rely solely on indigenous knowledge.

Mudimbe's lift metaphor and Lorde's litany, both cited earlier, illustrate the lack of autonomy that prevents African thought from possessing its own intellectual force. Imbo suggests that most African academics address their intellectual arguments to the African elite or Western scholars, thus 'smuggling' Western thought into African philosophy. ${ }^{181}$ Also the collection, documentation and preservation of indigenous knowledge renders it open to further dilution. ${ }^{182}$ While opening it up to commercialisation may aid its preservation, the survival of African thought as a unique product of Africa's lived experiences may be jeopardised. ${ }^{183}$ However, that is the advantage of decolonising thought. Indigenous thought serves no utilitarian purpose when preserved for the purpose of originality alone - it merely serves as an intellectual 'other'. Decolonising education suggests that all forms of knowledge equally complete our understanding of the world.

\section{Decolonising education: IHRL, Spivak, Freire and the value of educational research}

According to Smith, decolonisation is 'a social and political process aimed at undoing the multifaceted impacts of the colonial project and re-establishing strong contemporary indigenous nations and institutions based on traditional values, philosophies and knowledge'. 184 Hallen proposes that to decolonise knowledge 'involves reassessing academic philosophy's supposedly universal paradigms as Western paradigms. It involves arguing that any non-Western system of cognition deserves an equal hearing'. ${ }^{185}$ Decolonising education involves deconstruction, reconstruction, re-evaluation and recontestation of knowledge in Africa and the world. Our knowledge of Africa and knowledge in Africa should be completed by the history of Africa.

Colonialism was a geographically and psychologically veiled attack on the heterogeneity of human autonomy, knowledge and thought, ${ }^{186}$ from which humanity has not completely retreated. According to Spivak's discourse, colonialism operated as epistemic violence that silenced its subjects. She states that the voice of the precolonial was subjugated to 'a whole set of knowledges that have been disqualified as inadequate to their task or insufficiently elaborated: naive knowledges, located low down on the hierarchy, beneath the required level of cognition or scientificity'. ${ }^{187}$ According to Fricker, epistemic/hermeneutical injustice and marginalisation results when a group's social condition is obscured from collective understanding. ${ }^{188}$ Spivak argues that epistemic

180 Abagi (n 21) 306.

181 Imbo (n 76) 370.

182 Mkosi (n 137) 90.

183 Ibid.

184 Linda Tuhiwai Smith, Decolonizing Methodologies: Research and Indigenous Peoples (Zed Books 1999) 19 (emphasis added).

185 Hallen, The Good, the Bad (n 5) 34 (emphasis added).

186 Nyamnjoh (n 5) 132.

187 Spivak (n 11) 281.

188 Fricker (n 40) 152-69. 
violence can only be defused when the intellectual represents the silenced. ${ }^{189}$ However, the African intellectual lacks the structural capacity to represent; the Western intellectual lacks testimonial competence.

Consequently, decolonisation of education has to be focused on research-intensive, interdisciplinary, cross-cultural, egalitarian, overt, persistent, capacity-sharing and competence-building. ${ }^{190}$ As Maggio states: 'The academy is both part of the problem and part of the solution'.191 African states rely heavily on international governmental organisations for financial assistance; this assistance is often predicated on internal acquiescence with international norms that may have origins in colonial thought. ${ }^{192}$ Consequently, internal decolonisation of education is fettered by the international community. Surprisingly, communicative incompetence occurs within Africa as most of the issues explored in the preceding sections are not described in IHRL terms. ${ }^{193}$ International human rights groups do not engage with the daily social injustice struggles of populations, which leads to a disconnect between the aims of IHRL and domestic civil society 194 because the language of human rights has become a language of privilege. ${ }^{195}$ Taking a Freirian approach acknowledges the 'situationality' of African knowledge indigenous knowledge is static, but African knowledge is fluid and may (or may not) encompass indigenous knowledge. Indigenous knowledge that is anachronistic or irrelevant can be preserved as such - knowledge that was. As Hallen argues, knowledge should be democratised, and not defined by reference to a particular cultural worldview. ${ }^{196}$ Promoting a dominant worldview silences the non-dominant views. ${ }^{197}$ Knowledge that is anywhere should be knowledge everywhere.

Research is the heart of knowledge and education; research into education and the right to education should be aware of the vestiges of colonial knowledge in education. ${ }^{198}$ Taking a Freirian approach means that equal and collaborative research should be the main focus of external engagement with Africa. ${ }^{199}$ African researchers' originality and 'situationality' run the risk of being rejected for challenging accepted knowledge; thus the most strident academic African voices are diasporic. ${ }^{200}$ Intensive African input into collaborative research will ensure that African thought is not silenced and recolonised. ${ }^{201}$ Therefore, IHRL should continue to maintain the vanguard of the anticolonial movement.

Decolonising education in Africa should have as one of its focuses the liberating purpose of education. ${ }^{202}$ By focusing on humanism as a facet of the African worldview,

189 Ibid 285.

190 Higgs (n 169) 45; Wane (n 134) 239.

191 Joe Maggio, “Can the Subaltern Be Heard?" Political Theory, Translation, Representation, and Gayatri Chakravorty Spivak' (2007) 32(4) Alternatives: Global, Local, Political 420.

192 Ali A Abdi, 'Intensive Globalizations of African Education' in Abdi and Hérbert (n 156) 356-9.

193 Chidi Anselm Odinkalu, 'Why More Africans Don’t Use Human Rights Language' (2000) 2(1) Human Rights Dialogue 3.

194 Ibid.

195 Ibid.

196 Hallen, African Philosophy (n 5) 88.

197 Rutazibwa (n 20) 292; Shizha (n 5) 68.

198 Rutazibwa (n 20) 299; Shizha (n 18) 120.

199 Mama (n 55) 22; Nyamnjoh (n 5) 144-5, 148; Wane (n 134) 239, 242.

200 Nyamnjoh (n 5) 145, 148.

201 Rutazibwa (n 20) 294; Agyeyomah et al (n 108) 249.

202 Higgs (n 169) 50; Nyamnjoh (n 5) 145. 
equal attention would be given to all forms of knowledge: ${ }^{203}$ African identity would focus on 'looking out' rather than 'measuring up'; identity would be self-constructed, capable of dynamism, rather than exogenously constructed and static. ${ }^{204}$ National development requires citizens who can self-actualise and self-construct the desired future. Implementation of human rights in Africa should focus on the African mind as well as the African body, thus preserving human dignity. ${ }^{205}$ Accounting for the African worldview in African education allows for greater communal responsibility in sociopolitical national development because the African worldview emphasises individual responsibility to community. Civic education will demonstrate to participants in education that the fortunes of their nation rest on their actions.

Therefore, the main emphasis in decolonising education in Africa should involve a process of continuous and persistent critical engagement with, and selective incorporation of, African knowledge (precolonial or postcolonial), while simultaneously resisting the lure of the instinctive ascription of inferiority to different systems of knowledge. ${ }^{206}$ This would give voice to the voiceless African, ensure the socio-political development of her society, and increase the forms of knowing available globally. Quality, acceptable and adaptable education in Africa could ensure the implementation of the rights to development and good governance. ${ }^{207}$ Global implementation of the right to education should incorporate the best educational ideas and practices into our understanding of knowledge. 208

\section{Conclusion}

I have argued that un-decolonised education which results in epistemic violence is pedagogically unsound and violates the right to education. Limitations to reversing this in Africa include misconceptions about African knowledge systems and African structural inadequacies. Decolonising education can only be done internationally and within the framework of IHRL. As an African, who was schooled in Africa, I was taught that Mungo Park discovered the River Niger, which was never lost. As a member of the school debating club, I was often called upon to support the motion that colonialism was a good thing, without which we would have been living in trees, lacking government or politics. I was taught that we did not exist as identifiable peoples before colonialisation - we were called out of darkness and made from silence into organised states. Decolonisation of education, knowledge and thought recognises that there are several ways of knowing and being known. Decolonisation of education, knowledge and thought does not ask us to rewrite history, but should allow us Africans the academic freedom to finally write ours, as equal intellectual members of the human race.

203 Higgs (n 169) 50-51.

204 Hallen, African Pbilosophy (n 5) 102.

205 Babaci-Wilhite et al (n 13) 623.

206 Handel Kashope Wright et al, 'Guest Editorial: Rethinking the Place of African Worldviews and Ways of Knowing in Education' (2007) 1(4) Diaspora Indigenous and Minority Education 243-4; Babaci-Wilhite et al (n 13) 629.

207 Rutazibwa (n 20) 294.

208 Shizha (n 5) 73. 
